\title{
Measured and Modeled Historical Precipitation Trends for Svalbard
}

\author{
EIRIK J. Førland, Ketil IsAKSEn, JUlia LutZ, AND INGER HANSSEN-BAUER \\ Norwegian Meteorological Institute, Oslo, Norway \\ THOMAS VIKHAMAR SCHULER \\ Institute of Geoscience, University of Oslo, Oslo, Norway
}

Andreas Dobler, Herdis M. GJELten, AND DAgRUn VikHAMAR-SCHUleR ${ }^{\mathrm{a}}$

Norwegian Meteorological Institute, Oslo, Norway

(Manuscript received 25 October 2019, in final form 17 April 2020)

\begin{abstract}
Precipitation plays an important role in the Arctic hydrological cycle, affecting different areas like the surface energy budget and the mass balance of glaciers. Thus, accurate measurements of precipitation are crucial for physical process studies, but gauge measurements in the Arctic are sparse and subject to relocations and several gauge issues. From Svalbard, we analyze precipitation trends at six weather stations for the last 50-100 years by combining different observation series and adjusting for inhomogeneities. For the past 50 years, the measured annual precipitation has increased by $30 \%-45 \%$. However, precipitation measurements in the cold and windy climate are strongly influenced by gauge undercatch. Correcting for undercatch reduces the trend values by $10 \%$ points, since the fraction of solid precipitation has decreased and undercatch is larger for solid precipitation. Thus, precipitation corrected for undercatch should be used to study "true" precipitation trends in the Arctic. Precipitation over Svalbard has been modeled by downscaling reanalysis data to a spatial resolution of $1 \mathrm{~km}$. In general, the modeled annual precipitation is higher $(13 \%-175 \%)$ than the measured values and mainly higher than the precipitation corrected for undercatch. Although the model resolves orographic effects on a regional scale, the downscaling is not able to reproduce local orographic enhancement for onshore winds, nor local effects of rain shadow. The downscaled dataset explains approximately $60 \%$ of the interannual precipitation variability. The model-based trends during 1979-2018 are positive, but weaker $\left(\sim 4 \%\right.$ decade $\left.^{-1}\right)$ than the observed $\left(\sim 8 \%\right.$ decade $\left.^{-1}\right)$ trends.
\end{abstract}

\section{Introduction}

Precipitation in the Arctic affects the ocean and terrestrial freshwater budgets, the surface albedo and energy budget, as well as the mass balance of ice sheets, glaciers, and sea ice (AMAP 2017). During recent decades, tropospheric water vapor (Serreze et al. 2012) and precipitation (Hartmann et al. 2013; Willett et al. 2013; Hanssen-Bauer et al. 2019) have generally increased in the Arctic. The increased precipitation is linked to the general warming, partly driven by anthropogenic forcing,

\footnotetext{
${ }^{\text {a }}$ Current affiliation: Statkraft, Oslo, Norway.
}

Corresponding author: Eirik J. Førland, eirikjf@met.no and amplified in the Arctic due to several feedback effects (Vihma et al. 2016). However, the Arctic precipitation trends show large spatial variations and are sensitive to the time period and data source (Vihma et al. 2016). Climate models have captured this upward trend but they have limited success in reproducing regional details (Vihma et al. 2016). For instance, for the Canadian Arctic, Rapaić et al. (2015) found that the available reanalysis datasets provided a reasonable consistent picture of the increased precipitation since 1950, but that they exhibited different spatial, seasonal, and temporal variability, particularly for precipitation. Atmospheric reanalyses contain errors in physical processes in the Arctic atmosphere and their interaction with the Earth surface (Vihma et al. 2014), especially wet biases linked to inadequate representation of sea ice as 
well as inhomogeneities from changes in data streams (e.g., improved satellite data) and methods over time (AMAP 2017). In addition, reanalyses are affected by the lack of good observations and limited consideration on homogeneity of the data throughout the entire analysis period (Zhang et al. 2013).

Our study is motivated by the evidence that the Arctic hydrological cycle is accelerating and the poleward moisture transport is enhanced (Zhang et al. 2013; AMAP 2017), highlighting the need for more extensive and accurate observations, better process understanding, better models, and more extensive and systematic use of existing models (AMAP 2017). The Svalbard region $\left(74^{\circ}-81^{\circ} \mathrm{N}\right)$ lies within the primary pathway for the transport of atmospheric energy into the Arctic (Serreze et al. 2007) and is situated in one of the fastest-warming areas on Earth (Isaksen et al. 2016; Overland et al. 2018; HanssenBauer et al. 2019). Unfortunately, in situ precipitation observations from the Arctic are sparse and are subject to many site and gauge issues, such as windinduced undercatch, underestimation of trace precipitation amounts, wetting and evaporation loss, station/instrumental shifts, changes in measurement protocols and automation (Goodison et al. 1998; Yang et al. 2005). For the Svalbard region, a number of 50-100-yr-long precipitation series are available (Førland et al. 1997a; Hanssen-Bauer 2002; Førland et al. 2011; Hanssen-Bauer et al. 2019), comprising unique long-term precipitation records for the High Arctic.

The present analysis combines and extends these earlier studies by comparing trends based on historic observed precipitation with observations that were corrected for undercatch ("true" precipitation). Moreover, site-specific trends based on downscaled reanalysis are compared to the observed precipitation trends. Specifically, we address the following two main research questions (RQs) concerning Arctic precipitation.

\section{a. RQ1: Are there differences between historic trends from actual observations versus observations that were corrected for undercatch (true precipitation)?}

For the cold and windy Svalbard climate, with a large proportion of solid precipitation, Førland and HanssenBauer (2000) found that because of undercatch in the gauges, the true annual precipitation at western Spitsbergen was more than $50 \%$ higher than the actual measured amounts. Thus, to study historic trends as well as to validate model output, measured precipitation corrected for undercatch should be used (section $2 \mathrm{~b}$ ). To adjust the measured precipitation for undercatch, annual fractions of solid, mixed, and liquid precipitation are deduced and analyzed (section $4 \mathrm{c}$ ).

Trend studies should be based on long, homogeneous observation series. By combining series, two long-term homogenized composite series are established for the period 1911-2018. Further, all observation series are tested for homogeneity and any homogeneity break is adjusted (section 2c).

\section{b. RQ2: Does downscaled reanalysis reproduce a realistic picture of observed local precipitation totals and historic trends?}

For Spitsbergen, gauge measurements of precipitation are constrained to the western coastal areas, but to describe hydrological processes (runoff, flooding, snow accumulation/melting, glacier mass balance, etc.) for the entire archipelago, precipitation estimates are needed for ungauged areas as well. Østby et al. (2017) used a coupled energy balance model forced by ERA40 and ERA-Interim to downscale reanalysis data (including precipitation) over Svalbard to a spatial resolution of $1 \mathrm{~km}$. The resulting dataset (Sval-Imp) covers the period 1957-2018. By comparing this dataset to the observations, we explore whether it is suitable to represent the precipitation over Svalbard.

The precipitation in the mountainous Spitsbergen is strongly influenced by topography (Førland et al. 1997b). To study the orographic influence on spatial precipitation distribution and on modeling biases, a large-scale classification of atmospheric circulation is used (see section $3 b$ and appendix).

In this paper, data and methods are presented in section 2, and a comparison of measured and modeled (Sval-Imp) precipitation is discussed in section 3. In section 4 we outline historic precipitation trends and long-term variability. The research questions are discussed in section 5 , where we also present our conclusions.

\section{Data and methods}

The observations used in this study are from the Norwegian Meteorological Institute (MET Norway) climate archive (available at seklima.met.no), and Russian data for Barentsburg are provided by Saint Petersburg State University. The downscaled series from reanalysis are described in section $2 \mathrm{~d}$.

The statistical significance of trends is analyzed by the Mann-Kendall test (see, e.g., Gjelten et al. 2016), and smoothed long-term variability is illustrated by low-pass-filtered series using Gaussian weighting (see, e.g., Gjelten et al. 2016). We use the 


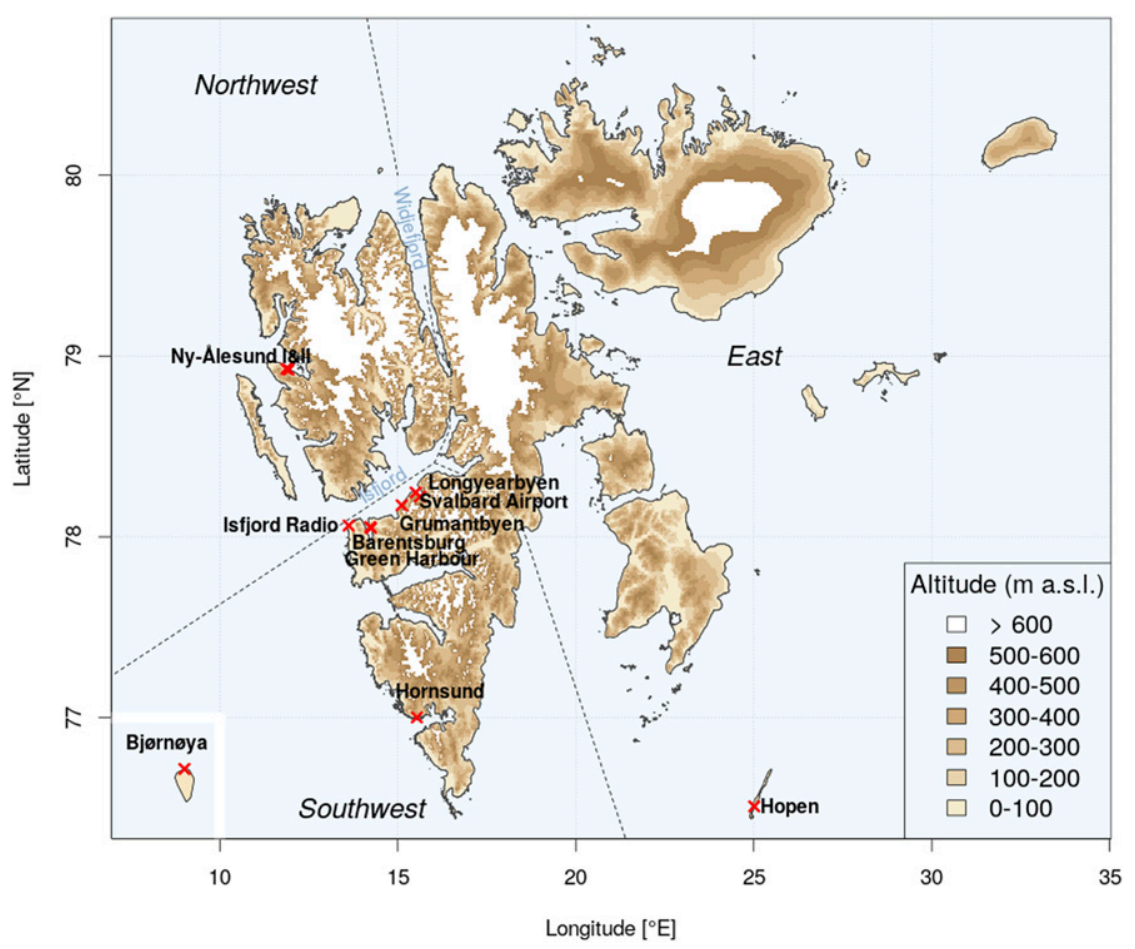

FIG. 1. Measuring sites for precipitation in the Svalbard region.

climatological standard normal period $1971-2000$ as the reference period in this study as this period is the basic period for studies of past and future climate changes in Norway (Hanssen-Bauer et al. 2017, 2019). For internal comparison of series we consider two other periods as well: 1969-2018 (including measurements for $\mathrm{Ny}-\mathrm{A} l e s u n d)$ and 1979-2018 (downscaled reanalysis based on ERA-Interim, see section $2 \mathrm{f})$.

\section{a. Measuring sites for precipitation}

The network of weather stations observing precipitation in the Svalbard region is sparse (see Fig. 1 and Table 1). Most of the stations are located on the west coast of Spitsbergen, and at low altitudes. MET Norway has in recent years established several automatic weather stations in the Svalbard region (see, e.g., Vikhamar-Schuler et al. 2019), but most of these do not include precipitation measurements.

\section{b. Problems measuring precipitation in the Arctic}

Precipitation series from the Arctic are influenced by substantial measuring errors caused by blowing/drifting snow (overcatch) on one hand and undercatch on the other hand. The wind induced undercatch of precipitation gauges has been recognized for many decades (e.g., Heberden 1769; Brown and Peck 1962; Sevruk
1982). In events with solid precipitation and strong winds, the hydrometeors are accelerated and deflected over the gauge and a substantial part of the precipitation is thus not collected by the gauges. Consequently, the measured precipitation may just be a small fraction of the true precipitation. In wind exposed areas on the Norwegian mainland, the precipitation gauges used by the Norwegian Meteorological Institute may catch less than $50 \%$ of the actual total winter precipitation (Førland and Aune 1985).

The estimates of undercatch in this paper are based on results from the WMO Solid Precipitation Measurement Intercomparison (Goodison et al. 1998) and field studies in Ny-Ålesund in the 1990s (Førland and HanssenBauer 2000). These field studies comprised 12-h manual measurements in the MET Norway and Russian Tretyakov precipitation gauges, as well as automatic measurements of wind speed, temperature, and precipitation intensity. For the MET Norway and Tretyakov gauges, coefficients for correcting measured values to provide estimates of true precipitation are available from Goodison et al. (1998). By use of these coefficients, and by combining the estimates of true precipitation based on measurements in the MET Norway and Tretyakov gauges in the Ny-Ålesund field studies, revised correction coefficients for the MET Norway gauge in the Svalbard region were 
TABLE 1. Stations measuring precipitation in the Svalbard region.

\begin{tabular}{|c|c|c|c|c|c|c|c|}
\hline Station No. & Station name & Abbreviation & Start & End & Alt (m MSL) & Lat $\left({ }^{\circ} \mathrm{N}\right)$ & Lon $\left({ }^{\circ} \mathrm{E}\right)$ \\
\hline 99710 & Bjørnøya & $\mathrm{BJ}$ & 1920 & & 16 & 74.5 & 19.0 \\
\hline 99720 & Hopen & $\mathrm{HO}$ & 1946 & & 6 & 76.5 & 25.0 \\
\hline 99754 & Hornsund & HS & 1978 & & 10 & 77.0 & 15.5 \\
\hline 99790 & Isfjord Radio & IS & $1934^{\mathrm{a}}$ & & 7 & 78.1 & 13.6 \\
\hline 99820 & Barentsburg/Green Harbour & BA & $1911^{\mathrm{b}}$ & & 40 & 78.1 & 14.2 \\
\hline 99840 & Svalbard Airport & SA & 1975 & & 28 & 78.2 & 15.5 \\
\hline 99860 & Longyearbyen & LO & $1916^{\mathrm{c}}$ & 1977 & 37 & 78.2 & 15.6 \\
\hline 99900 & Ny-Allesund I & NY & 1969 & 1974 & 42 & 78.9 & 11.9 \\
\hline 99910 & Ny-Ålesund & NY & 1974 & & 8 & 78.9 & 11.9 \\
\hline
\end{tabular}

${ }^{\text {a }}$ Gap in precipitation series 1976-2014.

${ }^{\mathrm{b}}$ Data from Green Harbour 1911-1930.

${ }^{\mathrm{c}}$ Extrapolated back to 1912 .

established (Hanssen-Bauer et al. 1996; Førland and Hanssen-Bauer 2000). For solid precipitation, these correction coefficients are a function of wind speed and air temperature, and for liquid precipitation of wind speed and rain intensity. Recent field studies in the Norwegian high mountains have confirmed that, except for high wind speeds, the use of the correction coefficients for solid precipitation deduced for Svalbard give feasible estimates of true precipitation (Wolff et al. 2015).

By using the deduced correction coefficients for Ny-Ålesund, Førland and Hanssen-Bauer (2000) found that for snow events the total precipitation corrected for undercatch was almost twice the actual measured amount. For the different seasons they found the following average ratios between the corrected and measured precipitation: winter $=1.70$, spring $=1.55$, summer $=1.25$, and autumn $=1.45$.

Due to lack of rainfall intensity data, and periods with low-quality wind speed records at the Norwegian Arctic stations, it is problematic to use the correction methodology (Førland and Hanssen-Bauer 2000; Wolff et al. 2013, 2015) on a daily basis for the historic precipitation series. To provide a rough estimate of true precipitation for long-term series, the average correction factors derived by Førland and Hanssen-Bauer (2000) for different precipitation types were applied. The MET Norway gauge is used at all Norwegian Arctic stations, and for this gauge the correction factor for snow is 1.85 , for rain 1.15 , and for mixed rain/snow or sleet 1.40 . The observers note the precipitation type according to the present and past weather codes defined by the World Meteorological Organization (WMO 2017). In this study, the main 12- or 24-h precipitation type was calculated based on WW (WMO Code Table 4677) and W1 (WMO Code Table 4561), respectively. For days with changing precipitation types the precipitation type at the time of the 0600 and
1800 UTC observation was chosen (0600 UTC for days where only 24-h observations were available). Only days with measured precipitation amounts of more than $0.0 \mathrm{~mm}$ are used.

\section{c. Inhomogeneities and combination of measured precipitation series in the Svalbard region}

Most decade- to century-scale time series of atmospheric data have been adversely impacted by inhomogeneities caused by, for example, changes in instruments, station moves, changes in local environment or in observing practices (Peterson et al. 1998). In the Svalbard region, there have been several relocations of stations as well as changes in instruments and environment (buildings) since the first permanent weather station was established in 1911. Because of the harsh and windy climate and large local climate gradients, even small relocations or instrumental changes at Arctic measuring sites may cause substantial changes (inhomogeneities) in the measuring conditions, for example, changes in overcatch or undercatch (section 2b). Furthermore, identification of inhomogeneities in Svalbard climate series is hampered by the sparse station network (Fig. 1). If not accounted for properly, the results of climate analyses using inhomogeneous data can be erroneous (Nordli et al. 1996; Peterson et al. 1998).

By combining series, homogenized and partly composite long-term precipitation series have been established for the key weather stations in the Svalbard region. Below is a brief metadata overview for precipitation observations at these stations. All stations were nonoperative for shorter or longer periods during the Second World War-missing seasonal and annual values for these years are interpolated as the mean of the five years before and after the data gap. More detailed metadata for the Norwegian Arctic stations may be found in Steffensen et al. (1996), 
Nordli et al. (1996), Førland et al. (1997a), and Nordli et al. (2014). The homogenized precipitation series were procured from two separate homogeneity analyses. For series prior to 1995, Nordli et al. (1996) used the standard normal homogeneity test (SNHT; see Alexandersson 1986) and for the later part of the series Vikhamar-Schuler et al. (2019) used the homogenization software HOMER (Mestre et al. 2013). The HOMER and SNHT methodologies produce break years as well as adjustment factors by comparing the time series to other series in the region.

\section{1) BJøRNØYA}

The station was established in 1920 . The precipitation series is adjusted for two homogeneity breaks (Nordli et al. 1996): one in 1926 connected to installation of a windshield around the gauge that increased the gauge catch during winter, and one because of a relocation in 1947 that decreased the gauge catch during winter. The gauge catch in summer was not affected.

\section{2) HOPEN}

Regular precipitation measurements started in October 1945. The precipitation series is adjusted for two inhomogeneities. Nordli et al. (1996) detected a break in 1974 caused by several environmental changes. Vikhamar-Schuler et al. (2019) revealed a severe homogeneity break after a relocation of the gauge in 1997: The adjustment factor for annual precipitation was 0.60 , with adjustment factors of 0.4 and 0.8 for winter and summer months, respectively; that is, the average winter precipitation measured at the new site is less than half of the values at the old site. The large homogeneity break is probably connected to a combination of strong winds and large proportions of solid precipitation on Hopen. The new site may be more exposed to wind (undercatch) and less influenced by drifting snow (overcatch) than the old site. During summer most of the precipitation is falling as rain, and consequently the influence of overcatch and undercatch is smaller. This is reflected in lower factors for inhomogeneity adjustment for the summer season.

\section{3) ISFJORD RADIO}

The station was established in 1934 but was destroyed by war actions in September 1941. The station was reestablished at the same site in August 1946 but closed down in June 1976. A new automatic weather station was installed in 2014, and (automatic) precipitation recordings were resumed in 2015 . No precipitation data exist for the period 1976-2014. The precipitation series is adjusted for homogeneity breaks in 1939,1958 , and 1966 (Nordli et al. 1996).

\section{4) Barentsburg/Green Harbour}

The weather station in Green Harbour was established on 1 December 1911, but the equipment for precipitation measurements was not of a conventional type (Førland et al. 1997a). The precipitation gauge was relocated and equipped with a windshield in 1924. This led to increased gauge catch during all seasons except summer, and the series is adjusted for this inhomogeneity (Nordli et al. 1996). However, the data from the years before 1924 are not reliable because of the unconventional "gauge" for precipitation measurements. The Green Harbour station was closed down in 1930. A Russian weather station was established in Grumantbyen in 1931 and moved to Barentsburg in 1933. The precipitation data for Barentsburg for the years 1931-33 are probably from Grumantbyen $(\sim 20 \mathrm{~km}$ east-notheast of Barentsburg). The gauge site in Barentsburg is located only $2.5 \mathrm{~km}$ north of the Green Harbour site, but a homogeneity break was detected and adjusted when the Green Harbour and Barentsburg series were joined (Nordli et al. 1996). The composite Green Harbour/Barentsburg precipitation series is adjusted for homogeneity breaks in 1931, 1956, 1978, and 1984 (Nordli et al. 1996).

\section{5) SVAlbard AIRPORT/LONGYEARBYEN}

Weather measurements in Longyearbyen started in November 1916, but up to 1957 there were several relocations and data gaps, as well as sparse metadata. From January 1957 to July 1977 a regular weather station was in operation. In August 1975, a weather station was established at Svalbard Airport, around $5 \mathrm{~km}$ northwest of Longyearbyen (Fig. 1). Despite several relocations, only one inhomogeneity in 1923 was found by Nordli et al. (1996). Data from Green Harbour were used to extrapolate the series further back to 1912 (Førland et al. 1997a). However, the recent homogeneity tests revealed that a small relocation of the precipitation gauge at the airport in October 2004 caused a homogeneity break (Vikhamar-Schuler et al. 2019). The series used in this study is adjusted for these two homogeneity breaks.

\section{6) NY-ÅLESUND}

During the years 1950-53 and 1961-68 irregular measurements were performed, but the first regular weather station was established in 1969. In July 1974, the station was relocated and this led to an increased gauge catch, especially in winter and spring, and the precipitation series had to be adjusted (Nordli et al. 1996). 


\section{d. Modeled precipitation from reanalysis: Description of the Sval-Imp dataset}

The Svalbard Impact assessment forcing dataset, Sval-Imp (Schuler and Østby 2020; Østby et al. 2017), comprises atmospheric variables required to force surface-energy balance based process models (temperature, radiation components, wind speed, humidity, and precipitation). Sval-Imp is gridded at a $1-\mathrm{km}$ resolution and at time steps of $6 \mathrm{~h}$ covering the period 19572018. The dataset has been created by downscaling reanalyses of the European Centre for Medium-Range Weather Forecast (ECMWF), namely, ERA40 (19572002; Uppala et al. 2005) and ERA-Interim (1979 onward; Dee et al. 2011), using a method of intermediate complexity involving a blend of interpolation techniques and simplified dynamics.

Typically, global reanalyses come at a resolution of $50-80 \mathrm{~km}$, too coarse to adequately represent the rough topography of Svalbard. Consequently, the fields of atmospheric variables at surface level lack spatial detail and are often heavily biased due to underestimating topographic effects. The methodology for downscaling temperature and radiation in Sval-Imp closely follows the TopoSub model (Fiddes and Gruber 2014), accounting for the effects of the high resolution topography as well as preserving the vertical structure of the atmosphere in the large-scale reanalysis. To resolve the orographic enhancement of precipitation at the $1-\mathrm{km}$ scale, a simple dynamical model of orographic precipitation (Smith and Barstad 2004) has been adopted. In various earlier applications (Barstad and Smith 2005; Crochet et al. 2007; Schuler et al. 2008; Jarosch et al. 2012), this model has been found valuable in providing spatial detail and reducing the bias in precipitation amount.

The dataset was originally produced for running a surface energy balance model to simulate spatial and temporal variations of glacier mass balance, but is useful for similar applications of land surface models, such as for snow and permafrost (Aalstad et al. 2018), terrestrial ecology (Botnen 2020), or hydrology (HanssenBauer et al. 2019). The dataset is publicly available at https://archive.sigma2.no/pages/public/datasetDetail.jsf? id=10.11582/2018.00006 (Schuler 2018).

\section{e. Downscaling and interpolation to specific locations}

For comparison with observational records, time series have been extracted from the grid point closest to the location of each individual weather station. The exception is Bjørnøya, which is not covered by the spatial extent of Sval-Imp (Vikhamar-Schuler et al. 2019). Continuous time series have been constructed by

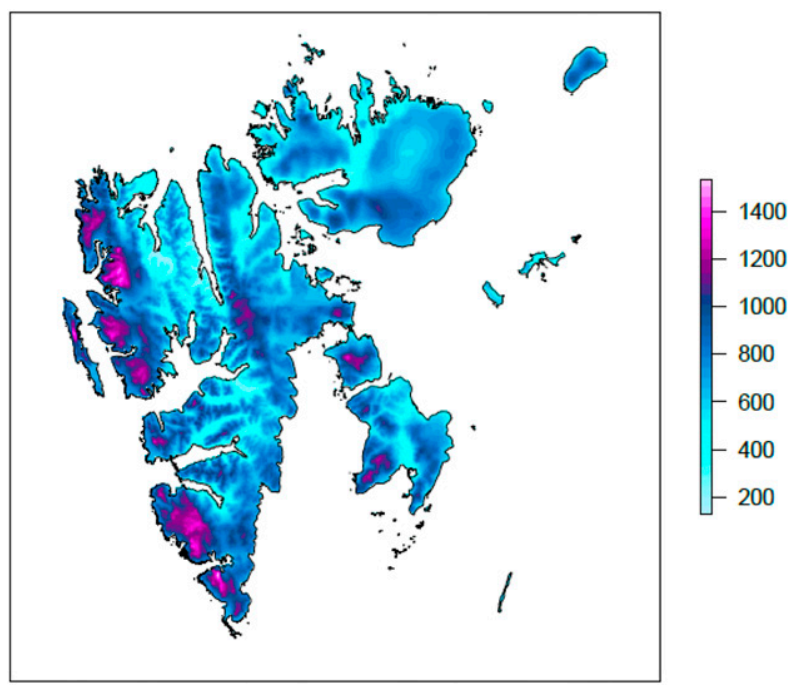

FIG. 2. Modeled annual precipitation ( $\mathrm{mm}$ ) from the Sval-Imp dataset averaged over the period 1971-2000.

concatenating the downscaled ERA40 for the period September 1957-December 1978 and ERA-Interim from January 1979 onward. To match the temporal resolution of observations, the extracted time series have been temporally aggregated into daily values $(0600$ 0600 UTC) for precipitation (sum) and temperature (mean).

\section{f. Uncertainties and inhomogeneities in the Sval-Imp dataset}

In an evaluation of reanalysis datasets for the Canadian Arctic, Rapaić et al. (2015) underscores the need to take particular care when using such datasets, especially for precipitation. Uncertainties in the SvalImp dataset are related to shortcomings of the downscaling methodology, for instance arising from situations that violate simplifying assumptions, and uncertainties inherent in the large-scale reanalysis. The latter contain uncertainties related to the model used for the reanalysis and the observations assimilated in the analysis step. As such, the amount, quality, and spatial coverage of observations assimilated vary, thus introducing heterogeneity in the reanalysis. The inclusion of satellite data for the period after 1979 has noticeable effect on the reanalysis, especially in otherwise data-sparse areas like the Arctic. The composite Sval-Imp dataset contains a discontinuity around 1979 due to concatenating two different reanalyses. Østby et al. (2017) investigated the influence of this heterogeneity for the period 1979-2002 when both reanalyses overlap. In the present paper, the validation of Sval-Imp data versus observations supports the assumption of a discontinuity due to the 
TABLE 2. Annual and seasonal precipitation ( $\mathrm{mm}$ ) averaged over 1979-2018. "Measured" is based on homogenized observational series, and "modeled" is based on the Sval-Imp dataset. The dash indicates not available. ANN = annual.

\begin{tabular}{|c|c|c|c|c|c|c|c|c|c|c|}
\hline \multirow[b]{2}{*}{ Locations } & \multicolumn{5}{|c|}{ Measured } & \multicolumn{5}{|c|}{ Modeled (Sval-Imp) } \\
\hline & ANN & MAM & JJA & SON & DJF & ANN & MAM & JJA & SON & DJF \\
\hline Bjørnøya & 425 & 93 & 75 & 129 & 129 & - & - & - & - & - \\
\hline Hopen & 295 & 63 & 74 & 88 & 69 & 546 & 111 & 114 & 181 & 137 \\
\hline Hornsund & 453 & 73 & 117 & 166 & 97 & 748 & 157 & 158 & 232 & 201 \\
\hline Barentsburg & 568 & 127 & 88 & 180 & 171 & 642 & 132 & 157 & 192 & 162 \\
\hline Svalbard Airport & 182 & 31 & 50 & 52 & 48 & 501 & 102 & 133 & 143 & 123 \\
\hline Ny-Ålesund & 447 & 89 & 84 & 142 & 130 & 658 & 134 & 159 & 194 & 170 \\
\hline
\end{tabular}

concatenation of ERA40 and ERA-Interim in 1979 (section 4d). Accordingly, most comparisons of SvalImp data and observations are focusing on the period 1979-2018.

\section{Comparison of modeled and measured precipitation values}

\section{a. Precipitation totals from measurements and Sval-Imp}

Figure 2 demonstrates large spatial variations in modeled annual precipitation over Svalbard. While values exceed $1200 \mathrm{~mm} \mathrm{yr}^{-1}$ in the western mountain areas, they hardly reach $400 \mathrm{~mm} \mathrm{yr}^{-1}$ in interior fjord and valley areas, for example, Longyearbyen. Large local differences are reflected in the measured values as well: Table 2 shows that the measured annual precipitation in Ny-Ålesund is more than twice the value at Svalbard Airport. At Barentsburg, the measured annual precipitation is about 3 times as high as the value measured at Svalbard Airport, even though it is only $34 \mathrm{~km}$ away. Apparently, the Svalbard Airport/Longyearbyen area is situated in a "rain shadow," sheltered by the surrounding mountains.

For all stations, the highest seasonal precipitation is found for autumn, while spring or summer have the lowest values. In general, the months May and June are the driest, and September and October the wettest (Hanssen-Bauer et al. 2019). Except for Bjørnøya, all stations have a secondary precipitation maximum in March.

The modeled precipitation is higher than the measured precipitation for all stations and all seasons (Table 2). The largest discrepancy is found for Svalbard Airport where the modeled annual precipitation is almost 3 times as high as measured. Similarly to the measured values, also the modeled precipitation is lower for Svalbard Airport than for the other Spitsbergen stations. But while the measured precipitation at Svalbard Airport is less than $50 \%$ of the values in Barentsburg and $\mathrm{Ny}$-Ålesund, the modeled values are just $25 \%$ lower. Although the Sval-Imp dataset gives higher precipitation values for Barentsburg and Ny-Ålesund than for Svalbard Airport, the topography resolved in the underlying model is probably not sufficient to fully reproduce the local rain shadow effect in the sheltered Svalbard Airport/Longyearbyen area.

\section{b. Bias between measured and modeled precipitation for different circulation types}

To illustrate whether the bias between modeled and measured precipitation is influenced by the large-scale wind pattern, the observed precipitation corrected for undercatch is assigned to different atmospheric circulation types (Fig. A1), based on a classification by Niedźwiedź (2013). The modeled values largely follow the pattern of the observed precipitation for all circulation types but are generally higher than the observed values (Figs. A1a-c). For Hopen and Ny-Ålesund, there is a fairly good accordance between modeled and corrected precipitation for all circulation types, except for southeasterly winds at Hopen (Fig. A1d). For Svalbard

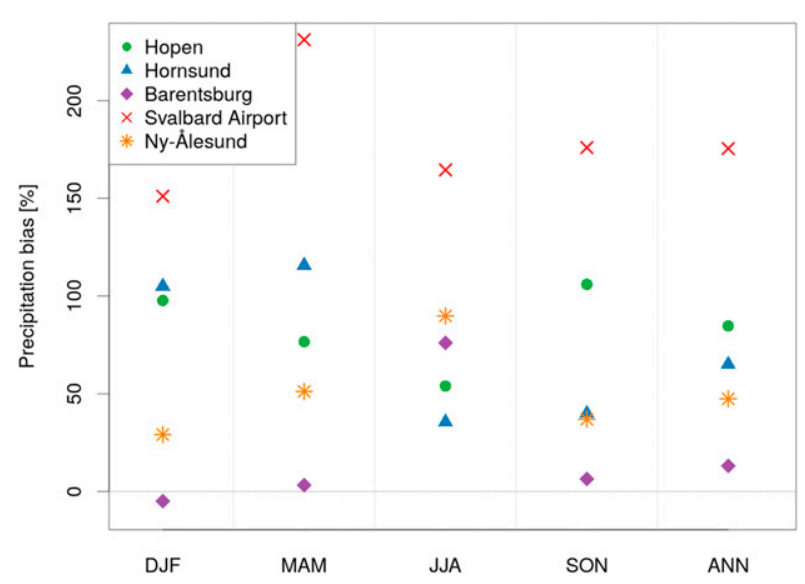

FIG. 3. Relative bias (\%) in annual and seasonal precipitation between the modeled (Sval-Imp) data and the observations for the years 1979-2018. 
a)

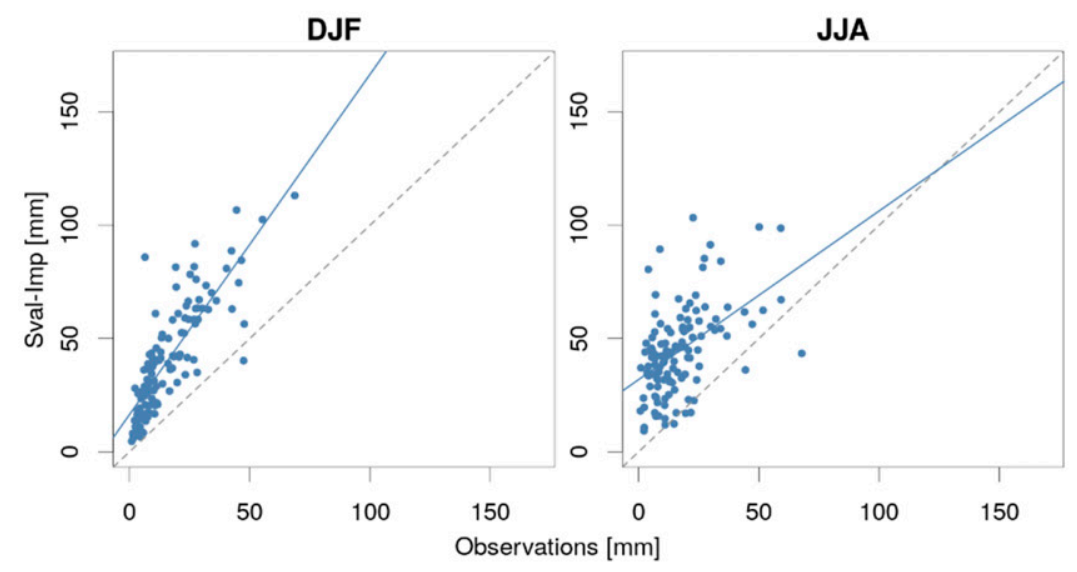

b)

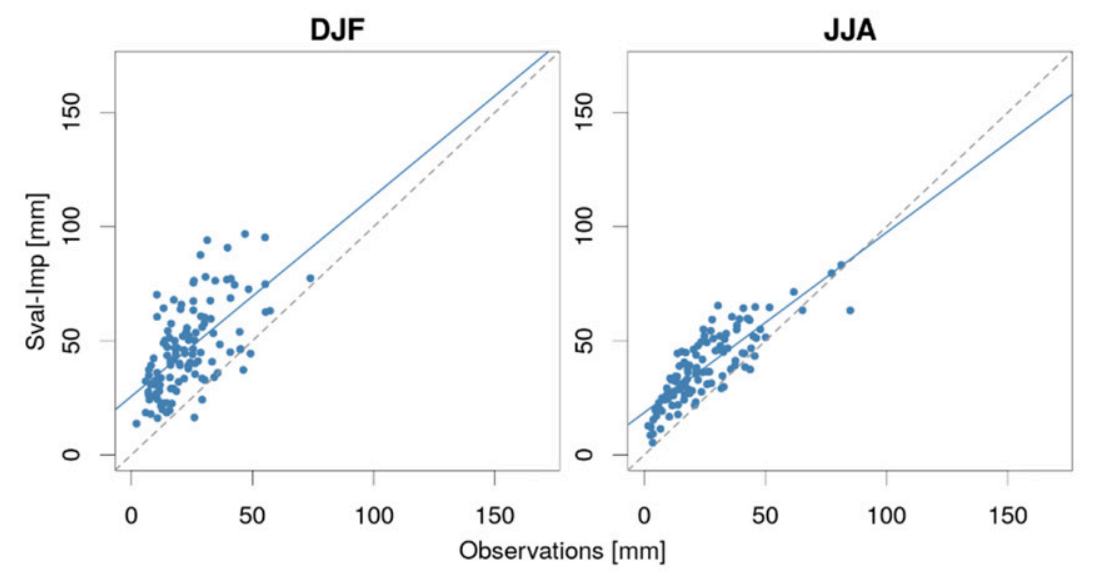

c)

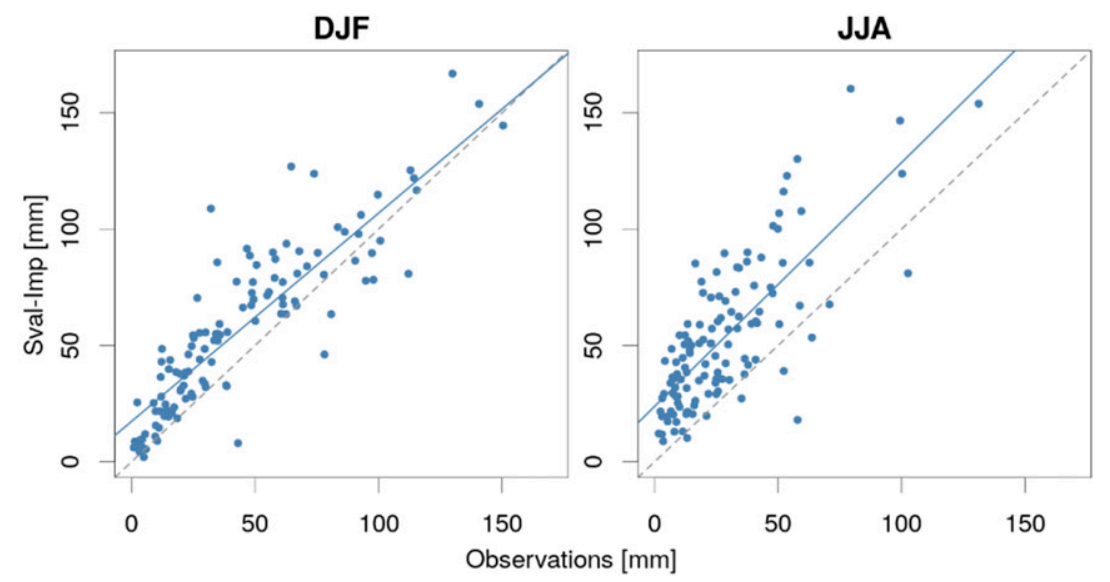

FIG. 4. Examples of scatterplots for monthly precipitation from observations and modeled (Sval-Imp) dataset for (a) Svalbard Airport, (b) Hopen, and (c) Ny-Ålesund for the years 1979-2018. The blue lines indicate the regression line between modeled data and observations, while the dashed lines show the 1:1 line. (left) Winter months (DJF) and (right) summer months (JJA). 
Airport, the modeled values are more than twice the observed precipitation for large-scale winds from the sector west to north. Interestingly, the bias between modeled and measured precipitation is low for circulation types where cyclones or cyclonic troughs are situated over or near Spitsbergen. For these circulation types, the wind speeds over Spitsbergen are generally low. The characteristics of the biases between modeled and observed precipitation may thus be interpreted in the following way: the downscaled reanalysis does give a good general representation of the precipitation processes (small biases for circulation types $\mathrm{Cc}$ and $\mathrm{Bc}$ ), but does not reproduce the local orographic effects caused by the large-scale wind direction (larger biases for onshore winds).

\section{c. Correlation between measured and modeled precipitation}

To compare the Sval-Imp precipitation data with the measurements further, we have computed relative biases between the Sval-Imp dataset and the observations, that is,

$$
\text { relative bias }=\frac{\operatorname{Prec}_{\mathrm{Sval}_{-\mathrm{Imp}}}-\mathrm{Prec}_{\mathrm{Obs}}}{\operatorname{Prec}_{\mathrm{Obs}}} .
$$

Figure 3 shows the biases averaged over the whole year and over the four seasons to summarize the results. Note that only the stations with long and homogenized observed time series are accounted for. As already discussed in section $3 \mathrm{a}$, the highest biases, with values over $150 \%$, can be found for Svalbard Airport. Barentsburg exhibits the lowest biases, closely followed by $\mathrm{Ny}$-Ålesund. Interestingly, both stations show a relatively high bias in the summer months (JJA), so that Hopen and Hornsund have even lower values in this season.

Figure 4 shows examples of scatterplots for measured and modeled monthly precipitation from three weather stations and their corresponding grid points. The best correlation for the winter months (DJF) can be found for $\mathrm{Ny}$-Ålesund, whereas Hopen features the best correlation for the summer months (JJA). However, at all three stations the precipitation from the Sval-Imp dataset is generally higher than the observed precipitation, and this is especially true for Svalbard Airport.

Figure 5 summarizes the correlations between the observed and modeled seasonal and annual sums of precipitation for the same stations as Fig. 3. To simplify the illustration, only the coefficient of determination $\left(r^{2}\right)$ is shown. Coefficient $r^{2}$ is considerably lower for precipitation than for temperature (see Fig. 3.7 in

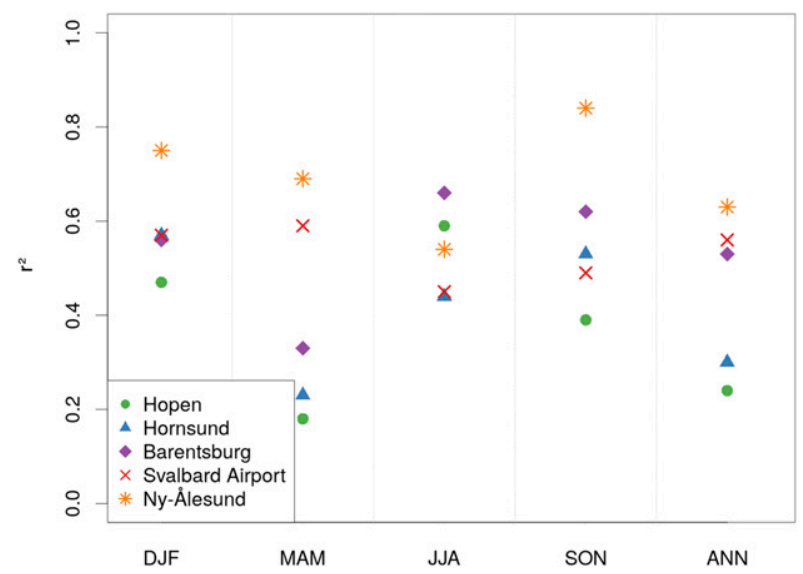

FIG. 5. Coefficient of determination $\left(r^{2}\right)$ between precipitation from observations and modeled data for the years 1979-2018 at selected observational sites.

Vikhamar-Schuler et al. 2019) and the variability of $r^{2}$ for precipitation is very high, the values reach from 0.18 to 0.84 . This indicates that the modeled precipitation does not necessarily reproduce the observed for a specific season and station. Reasons for this may be the exact station location, land-sea or sea ice contrasts and other local effects which are not well represented in the downscaling approach, even at $1 \mathrm{~km} \times 1 \mathrm{~km}$ target resolution. For instance, the Hopen station is situated at the eastern edge of the island and thus is exposed to the most precipitation contributing circulation types (see section 3a).

The lowest $r^{2}$ can be found for Hopen with one exception: in summer, Hopen exhibits the second

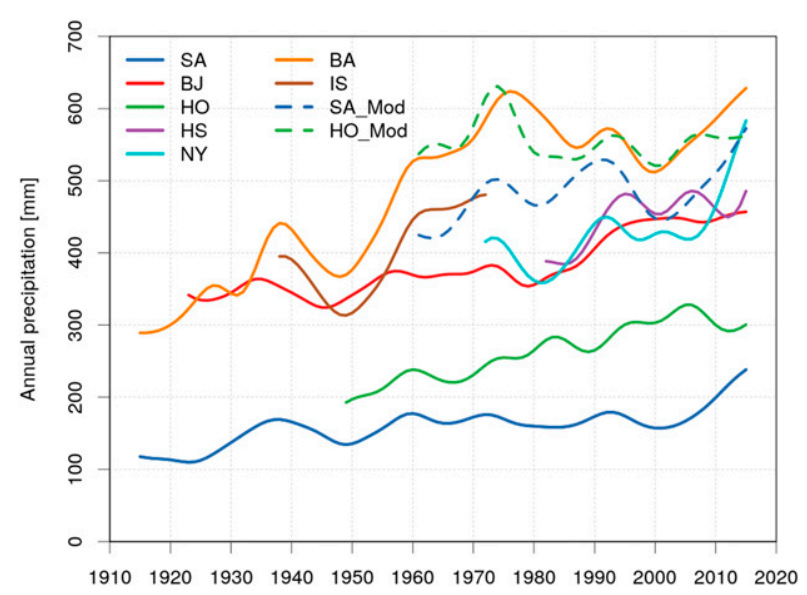

FIG. 6. Time series of homogenized measured annual precipitation (solid lines) and modeled (Mod) annual precipitation (dashed lines). The series are smoothed by Gaussian weighting coefficients and show variability on a decadal time scale; they are cut 3 years from start and end. For abbreviations of station names, see Table 1. 
TABLE 3. Ratios between annual precipitation for different 30-yr periods ( $\mathrm{I}=1961-90, \mathrm{II}=1989-2018)$ vs the reference period $1971-2000$ for measured, modeled, and corrected precipitation. "Avg"' is average during 1971-2000. A dash indicates not available.

\begin{tabular}{|c|c|c|c|c|c|c|c|c|}
\hline & \multicolumn{3}{|c|}{ Measured } & \multicolumn{3}{|c|}{ Modeled } & \multicolumn{2}{|c|}{ Corrected } \\
\hline & $\operatorname{Avg}(\mathrm{mm})$ & Ratio I & Ratio II & $\operatorname{Avg}(\mathrm{mm})$ & Ratio I & Ratio II & $\operatorname{Avg}(\mathrm{mm})$ & Ratio II \\
\hline Bjørnøya & 396 & 0.93 & 1.12 & - & - & - & 571 & 1.09 \\
\hline Hopen & 276 & 0.91 & 1.10 & 566 & 0.99 & 0.98 & 428 & 1.05 \\
\hline Hornsund $^{\mathrm{a}}$ & 429 & 0.94 & 1.12 & 796 & 0.99 & 0.98 & - & - \\
\hline Barentsburg & 574 & 0.98 & 1.00 & 656 & 0.97 & 0.99 & - & - \\
\hline Svalbard Airport & 168 & 0.97 & 1.13 & 495 & 0.95 & 1.03 & 253 & 1.08 \\
\hline Ny-Ålesund ${ }^{\mathrm{b}}$ & 409 & 0.94 & 1.15 & 672 & 0.93 & 0.99 & 621 & 1.11 \\
\hline
\end{tabular}

${ }^{a}$ Data from July 1978.

${ }^{\text {b }}$ Average values for 1961-90 are interpolated (Førland et al. 1997a).

highest $r^{2}$ value, whereas Hornsund and Svalbard Airport show the lowest $r^{2}$. Generally, the highest $r^{2}$ values can be found for Ny-Ålesund (except in summer), demonstrating that for this station the Sval-Imp dataset is able to explain about $70 \%-85 \%$ of the interseasonal variability in autumn, winter, and spring. Except for Hopen and Hornsund, Sval-Imp is able to explain around $60 \%$ of the interannual variability.

\section{Historical variability and trends}

\section{a. Long-term variations in annual precipitation}

The observed annual precipitation series show quite different individual long-term patterns (Fig. 6). This is in contrast to the temperature series, which show similar long-term temporal variability (Hanssen-Bauer et al.2019). The main reason is that precipitation varies locally on a smaller spatial scale than air temperature. However, most precipitation series show increasing precipitation throughout their measuring period. Svalbard Airport, Ny-Ålesund, and Barentsburg exhibit a distinct increase during the most recent decades. Also the modeled series (Fig. 8) for these stations show increasing precipitation in recent years. However, Hopen does not follow this pattern.

Table 3 shows the differences in measured as well as modeled annual precipitation between the Norwegian reference period 1971-2000 and two other 30 -yr periods. For the period 1961-90 (WMO climatological reference period), the observed precipitation is $2 \%-9 \%$ lower than during the Norwegian reference period (Ratio I), while for the latest 30-yr period (1989-2018) all stations except Barentsburg exhibit $10 \%-15 \%$ higher precipitation than during 1971-2000 (Ratio II). The modeled values show only minor differences between the three periods, but a tendency to higher values for the reference period
1971-2000. The modeled values are, however, influenced by the homogeneity break in 1979 (section 2f).

The differences between ratios computed from observations and model data are reduced when the observations are corrected for undercatch (Table 3, right column). Possible reasons for the differences between observed and modeled precipitation changes are discussed further in section $4 \mathrm{~d}$.

\section{b. Trends in measured and modeled annual and seasonal precipitation}

Linear precipitation trends for the Svalbard stations are outlined in Table 4. The left part presents trends from the start of the series, while the middle part shows trends from 1969 (the starting year of the Ny-Ålesund series). The trends in precipitation corrected for undercatch (lower part of Table 4) are discussed in section 4d. For the three longest series (Svalbard Airport, Barentsburg, and Bjørnøya), the (statistically significant) centennial trends for measured annual precipitation show a linear increase of $3 \%-6 \%$ decade $^{-1}$, with positive trends for all seasons. For Barentsburg and Svalbard Airport, the seasonal trend is highest for the autumn season, while for Bjørnøya the largest increase is found for the spring season.

For the past 50 years (from 1969 to present, Table 4, center), all observationally based series except Barentsburg show statistically significant positive trends of $6 \%-9 \%$ decade $^{-1}$ in annual precipitation. For autumn and winter, some positive seasonal trends exceed $15 \%$ decade $^{-1}$. For spring, there is a tendency of (nonsignificant) negative trends for all Spitsbergen stations. In summer, all trends are small. Annual as well as seasonal trends for Barentsburg deviate from similar trends at Svalbard Airport and Ny-Ålesund.

For the period 1979-2018 (Table 4, right), when SvalImp is forced by ERA-Interim (section 2f), the observation based trends show similar main features as for the period 1969-2018: Significant positive trends in some of the annual values, and for the Spitsbergen series also in 
TABLE 4. Linear precipitation trends ( $\%$ decade $^{-1}$ relative to the 1971-2000 average) in the Svalbard region. Trends are presented for measured precipitation and precipitation corrected for undercatch. Trends statistically significant at the $5 \%$ level are marked in bold. A dash indicates not available.

\begin{tabular}{|c|c|c|c|c|c|c|c|c|c|c|c|c|c|c|c|c|}
\hline & \multirow[b]{2}{*}{ Start } & \multicolumn{5}{|c|}{ Start-2018 } & \multicolumn{5}{|c|}{ 1969-2018 } & \multicolumn{5}{|c|}{ 1979-2018 } \\
\hline & & ANN & DJF & MAM & JJA & SON & $\mathrm{ANN}$ & DJF & MAM & JJA & $\mathrm{SON}$ & $\mathrm{ANN}$ & DJF & MAM & JJA & SON \\
\hline \multicolumn{17}{|c|}{ Measured } \\
\hline Bjørnøya & 1920 & 3 & 5 & 5 & 0 & 3 & 6 & 12 & 12 & -4 & 4 & 7 & 10 & 8 & 3 & 6 \\
\hline Hopen & 1946 & 7 & 12 & 13 & 0 & 6 & 6 & 12 & 12 & -5 & 8 & 5 & 5 & 11 & -1 & 5 \\
\hline Hornsund & 1979 & 9 & 10 & -2 & -2 & 23 & - & - & - & - & - & 9 & 10 & -2 & -2 & 23 \\
\hline Barentsburg & 1912 & 6 & 5 & 6 & 4 & 7 & 1 & -1 & -2 & -4 & 6 & 3 & 0 & -1 & 0 & 8 \\
\hline Svalbard Airport & 1912 & 5 & 4 & 3 & 4 & 7 & 7 & 14 & -6 & 1 & 19 & 12 & 22 & -5 & 3 & 24 \\
\hline Ny-Ålesund & 1969 & 9 & 15 & -1 & 1 & 16 & 9 & 15 & -1 & 1 & 16 & 13 & 24 & -2 & 1 & 22 \\
\hline \multicolumn{17}{|c|}{ Corrected for undercatch } \\
\hline Bjørnøya & 1920 & - & - & - & - & - & 6 & 11 & 9 & -5 & 1 & 5 & 8 & 5 & 2 & 4 \\
\hline Hopen & 1946 & - & - & - & - & - & 4 & 11 & 8 & -4 & 4 & 0 & 2 & 8 & -1 & -1 \\
\hline Svalbard Airport & 1912 & - & - & - & - & - & 5 & 10 & -7 & 0 & 15 & 8 & 14 & -7 & 1 & 18 \\
\hline Ny-Ålesund & 1969 & - & - & - & - & - & 7 & 11 & -2 & 1 & 13 & 9 & 18 & -4 & -1 & 18 \\
\hline
\end{tabular}

some of the autumn and winter values. For the modeled series (Table 5) most trends are lower than the observation based trends, and none of the modeled trends are statistically significant in this period. For the five stations studied, the average trend based on measured values is $8.4 \%$ decade $^{-1}$ and for the modeled values $3.6 \%$ deca$\mathrm{de}^{-1}$. There may be several reasons for this discrepancy between observed and modeled series. Especially precipitation undercatch may result in too low observed values. The influence of an undercatch adjustment is discussed in detail in section $4 \mathrm{~d}$.

\section{c. Trends in precipitation types}

The trends in measured precipitation are influenced by variability in the precipitation type, as the undercatch depends on whether the precipitation is falling in solid or liquid form (section 2b). The annual fractions of solid, liquid, and mixed precipitation on Svalbard exhibit large year-to-year variations. For the period 1969-2018, the fraction of, for example, snow varies between $23 \%$ (2016) and 76\% (1998) at Ny-Ålesund and between $12 \%$ (2016) and 71\% (1982) at Svalbard Airport (see Fig. 7). However, Fig. 7 demonstrates that the annual fraction of solid precipitation during 1969-2018 has decreased at all stations studied. The negative trend for solid precipitation varies between $-2.3 \%$ decade $^{-1}$ (Bjørnøya) and $-6.5 \%$ decade $^{-1}$ (Hopen). For liquid precipitation, positive trends were found for all stations, varying between $0.6 \%$ decade $^{-1}$ (Bjørnøya) and 9.4\% decade ${ }^{-1}$ (Svalbard Airport). For mixed precipitation, the trends are weak (not shown).

\section{d. Influence of undercatch adjustment}

Series of precipitation corrected for undercatch (Table 6) are computed by the adjustment factors (given in section 2b) on the seasonal and annual fractions of solid, liquid, and mixed precipitation. The adjustment factors are based on weather conditions in Ny-Ålesund during July 1993-August 1995 (Hanssen-Bauer et al. 1996; Førland and Hanssen-Bauer 2000) and may differ for other years or sites with different wind conditions. However, to get a rough measure for the true precipitation, the adjustment factors deduced for $\mathrm{Ny}$-Ålesund are assumed to be valid also for Svalbard Airport, Hopen, and Bjørnøya. For Hornsund and Barentsburg, information on precipitation types was not available to the authors.

Annual precipitation that is corrected for undercatch is around $50 \%$ higher than the measured values (Table 6). The winter ratios are lower than the adjustment factor for snow, and the summer ratio is slightly higher than the adjustment factor for rain, as there may be snowfall events even in summer, and rain events (occasionally heavy rainfall) at all Svalbard stations even in the winter season. The seasonal ratios are well in line with the results from Ny-Ålesund during 1993-95 (see section 2b).

For modeled precipitation, Table 6 (center) shows that for most stations the annual precipitation is

TABLE 5. Linear trends ( $\%$ decade $^{-1}$ relative to the $1971-2000$ average) during 1979-2018 for modeled precipitation (Sval-Imp) in the Svalbard region. None of the trends are statistical significant at the $5 \%$ level.

\begin{tabular}{lrrrrr}
\hline \hline & ANN & DJF & MAM & JJA & SON \\
\hline Hopen & 2 & -1 & -2 & 7 & 4 \\
Hornsund & 1 & 6 & -4 & -4 & 4 \\
Barentsburg & 11 & 8 & -4 & 3 & 5 \\
Svalbard Airport & 4 & 5 & -3 & 6 & 7 \\
Ny-Ålesund & 0 & 7 & -9 & -7 & 11 \\
\hline
\end{tabular}


SOLID
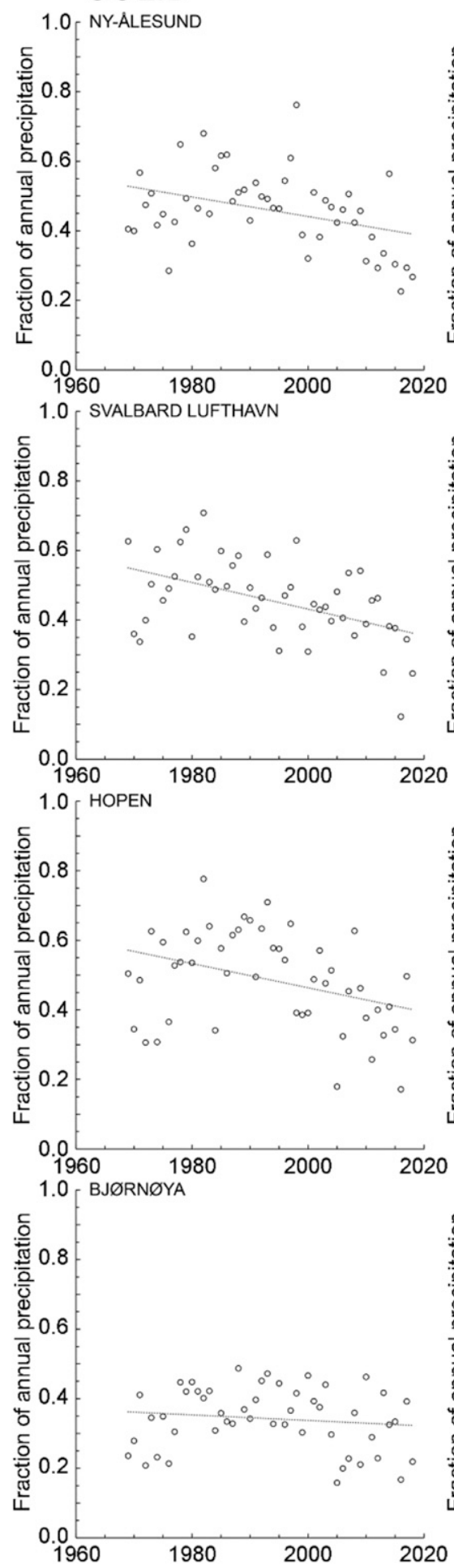

LIQUID
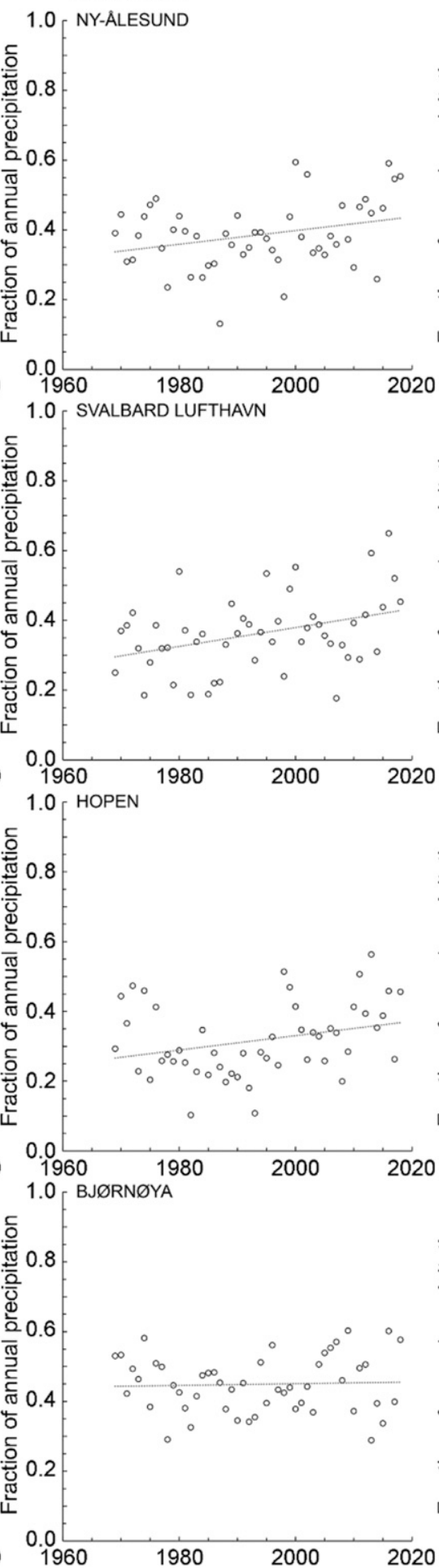

MIXED
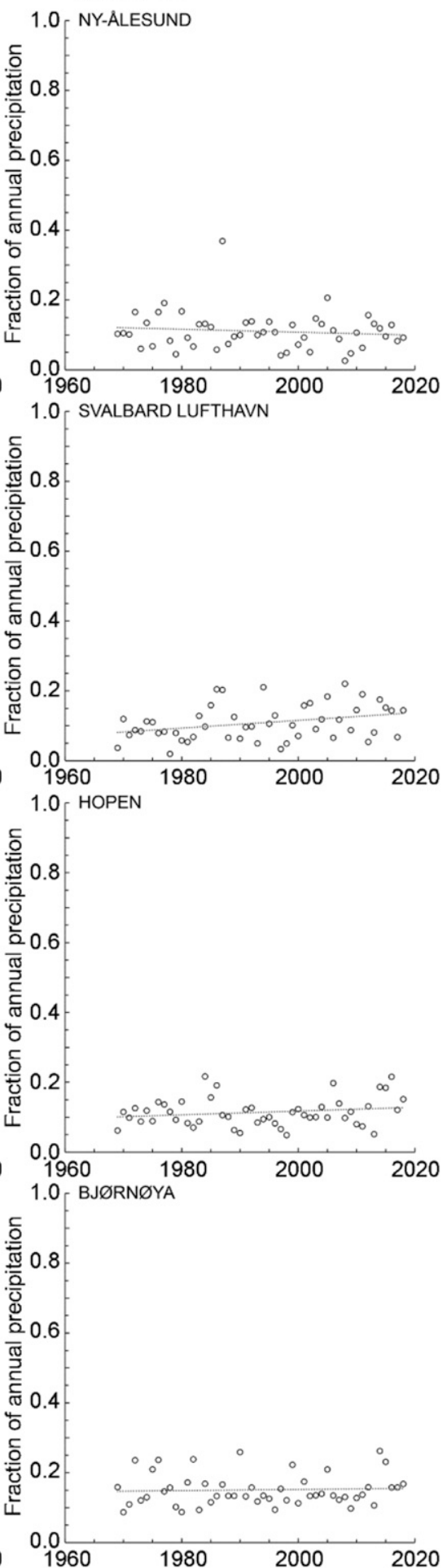

FIG. 7. Fraction of annual precipitation amount falling as (left) solid, (center) liquid, and (right) mixed precipitation at Ny-Ålesund, Svalbard Airport, Hopen, and Bjørnøya during 1969-2018. 
TABLE 6. Ratios for corrected (for undercatch), modeled (Sval-Imp), and measured (homogenized) precipitation during 1979-2018. A dash indicates not available.

\begin{tabular}{|c|c|c|c|c|c|c|c|c|c|c|c|c|c|c|c|}
\hline & \multicolumn{5}{|c|}{ Ratio corrected/measured } & \multicolumn{5}{|c|}{ Ratio modeled/measured } & \multicolumn{5}{|c|}{ Ratio modeled/corrected } \\
\hline & $\mathrm{ANN}$ & MAM & JJA & SON & DJF & ANN & MAM & JJA & SON & DJF & ANN & MAM & JJA & SON & $\overline{D J F}$ \\
\hline Bjørnøуа & 1.42 & 1.53 & 1.17 & 1.32 & 1.59 & - & - & - & - & - & - & - & - & - & - \\
\hline Hopen & 1.51 & 1.68 & 1.23 & 1.43 & 1.67 & 1.85 & 1.76 & 1.54 & 2.06 & 1.99 & 1.23 & 1.05 & 1.25 & 1.44 & 1.19 \\
\hline Hornsund & - & - & - & - & - & 1.65 & 2.15 & 1.35 & 1.40 & 2.07 & - & - & - & - & - \\
\hline Barentsburg & - & - & - & - & - & 1.13 & 1.04 & 1.78 & 1.07 & 0.95 & - & - & - & - & - \\
\hline Svalbard Airport & 1.47 & 1.65 & 1.18 & 1.42 & 1.69 & 2.75 & 3.29 & 2.66 & 2.75 & 2.56 & 1.88 & 2.00 & 2.25 & 1.93 & 1.52 \\
\hline Ny-Ålesund & 1.48 & 1.64 & 1.20 & 1.43 & 1.62 & 1.47 & 1.51 & 1.89 & 1.37 & 1.31 & 1.00 & 0.92 & 1.57 & 0.96 & 0.81 \\
\hline
\end{tabular}

substantially higher than the measured values. For Svalbard Airport, the modeled spring precipitation is more than triple the measured value. By correcting for undercatch, the apparent model overestimate is strongly reduced (Table 6 , right). For Ny-Ålesund, the modeled precipitation reproduces well the annual precipitation corrected for undercatch. However, the modeled summer precipitation is around $60 \%$ higher, and the winter
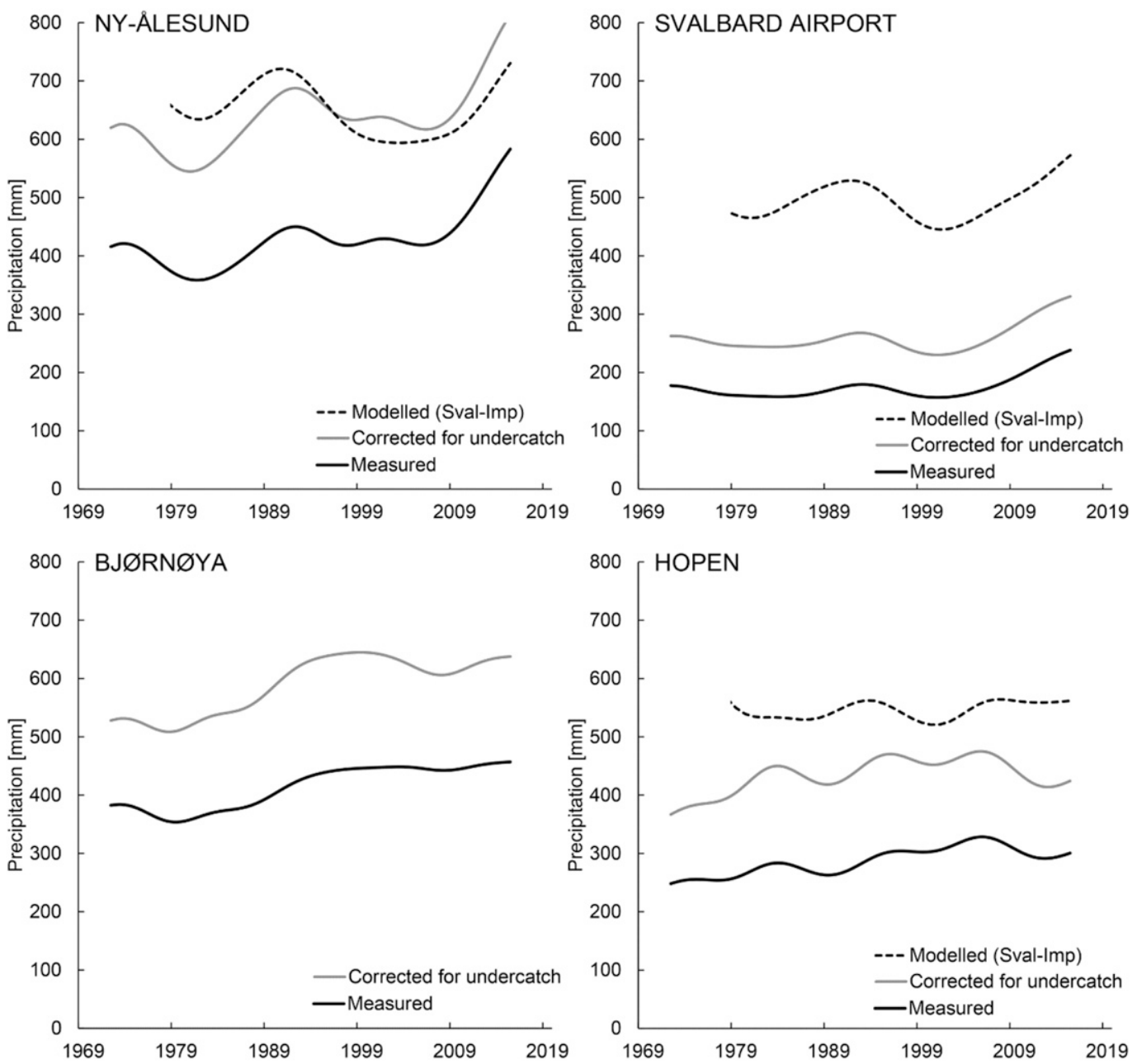

FIG. 8. Measured annual precipitation (black line), annual precipitation corrected for undercatch (gray line), and modeled annual precipitation (dashed line) at Ny-Ålesund, Svalbard Airport, Hopen, and Bjørnøya. The series are smoothed by Gaussian weighting coefficients and show variability on a decadal time scale. The smoothed curves are cut 3 years from start and end. Note that modeled annual precipitation start in 1979 when the Sval-Imp was based on ERA-Interim. 
precipitation around $20 \%$ lower than the precipitation corrected for undercatch. For Svalbard Airport, the modeled annual and seasonal precipitation is twice as high as the precipitation corrected for undercatch. For Hopen, the modeled annual precipitation is around $30 \%$ higher than the precipitation corrected for undercatch. But as mentioned in section $2 \mathrm{c}$, the annual measured precipitation at the site used after 1997 is just $60 \%$ of the level at the previous site. The representativity of the measurements at Hopen is therefore questionable.

Table 4 (center) shows that for the last 50 years, the decadal trends in corrected annual precipitation are approximately two percentage points lower than for the measured values, except at Bjørnøya, where the trends in precipitation types are very small. The seasonal trends are up to four percentage points lower, with the largest deviations in autumn, winter, and spring. During summer, most of the precipitation is falling as rain. Accordingly, Table 4 demonstrates that the trends for June-August are quite similar for measured precipitation and precipitation corrected for undercatch. For the last 40 years (Table 4, right), the pattern is the same, but the differences are even larger: up to five percentage points per decade in the annual trends and eight percentage points in the seasonal trends.

Figure 8 illustrates that the annual series for corrected precipitation from Ny-Ålesund and Hopen are closer to the modeled series than the actual observed series. For Svalbard Airport, even the precipitation corrected for undercatch is much lower than the modeled series (see also Tables 3 and 6). However, for Svalbard Airport as well as Ny-Ålesund, the modeled series do reproduce the main characteristics of the long-term development of the corrected annual precipitation.

To get a measure of time development in biases between modeled and measured precipitation, a time series is established for annual ratios between values from the Sval-Imp dataset and measured precipitation corrected for undercatch at Hopen, Svalbard Airport and Ny-Ålesund. Figure 9 indicates that for the modeled data, the overestimation of the corrected precipitation has decreased during the period 19692018 (the maximum in 1998 is due to a very high ratio at Svalbard Airport in that year). Apparently, three periods may be identified: up to 1978 the ratios are high (mean value 2.65 ) and the variability is large. During the years 1979-97, the ratios are still high (mean value 1.44), but generally lower than before 1979. From 1999 to present, the ratios are lower (mean value 1.34) than in the two previous periods, and the year-to-year variability is reduced (standard

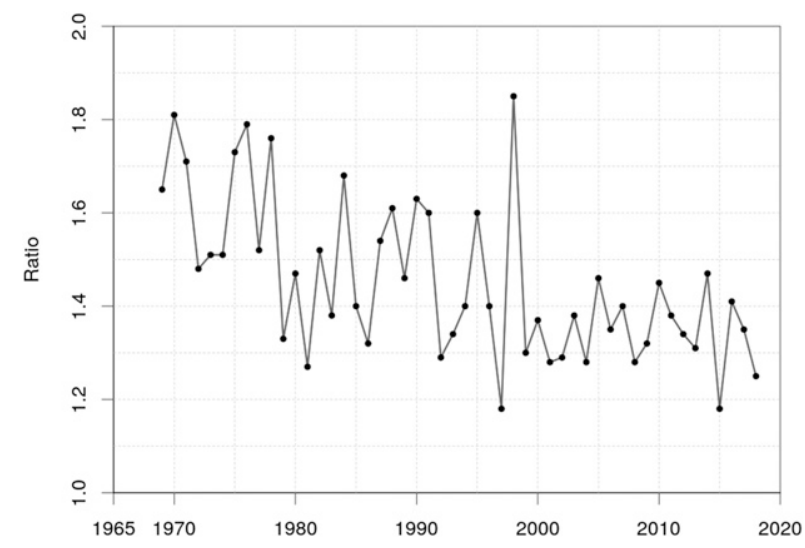

FIG. 9. Annual ratio between modeled precipitation and precipitation corrected for undercatch, averaged over values from Hopen, Svalbard Airport, and Ny-Ålesund.

deviation in ratios is reduced from 1.13 and 1.14 in the first two periods, and to 0.07 in the last period). The discontinuity around 1979 is discussed in section $2 \mathrm{f}$. The lower ratios and reduced interannual variability after 1999 may be the result of an increase in the data assimilated by ERA-Interim, specifically the number of aircraft reports (Dee et al. 2011) and high-quality satellite observations (Dee and Uppala 2009), leading to improvements in the simulated precipitation.

\section{Discussion and conclusions}

This study has analyzed historical precipitation trends over the last 50-100 years at six weather stations located in the Svalbard region. By combining different observation series, adjusted for inhomogeneities, and using modeled precipitation produced by downscaling reanalysis data, our conclusions are as follows:

- Two of the series, from Barentsburg and Longyearbyen/Svalbard Airport, are the longest precipitation series from the High Arctic. Since the start in the 1910s, the series show increasing annual precipitation $\left(3 \%-4 \%\right.$ decade $\left.^{-1}\right)$, particularly in the strong warming period after the year 2000 . The series exhibit a secondary maximum in the warm period in the 1930s and a secondary minimum in the cold period in the 1940s.

- For the past 50 years, the measured annual precipitation at the four long-term Norwegian weather stations (Bjørnøya, Hopen, Svalbard Airport, and $\mathrm{Ny}$-Ålesund) in the Svalbard region has increased by $30 \%-45 \%$.

- The annual fraction of solid precipitation for the four stations studied has decreased by $11 \%-32 \%$ 
during the years 1969-2018. On the other hand, the fraction of liquid precipitation has increased by $3 \%-46 \%$. For mixed precipitation, only weak temporal tendencies could be found. These changes in precipitation types may have consequences for hydrology, climatology, biology/ecosystem, and economy (see details in Bintanja and Andry 2017).

- The transition from solid to liquid precipitation in a warming Arctic influences the undercatch of the gauges. As a consequence, a larger portion of precipitation is collected. By correcting for undercatch, the trends in true annual precipitation for the past 50 years are around $10 \%$ points lower than indicated by the actual gauge measurements.

- For Ny-Ålesund, Svalbard Airport, and Barentsburg, precipitation modeled by downscaled reanalyses (Sval-Imp) may explain approximately $60 \%$ of the interannual precipitation variability. The modeled values do indicate positive trends during 19792018 in annual precipitation as well as for autumn (SON) and winter (DJF), but the average trends $\left(\sim 4 \%\right.$ decade $\left.^{-1}\right)$ are weaker than for observed precipitation $\left(\sim 8 \%\right.$ decade $\left.^{-1}\right)$ and statistically not significant.

- The modeled precipitation is higher $(13 \%-175 \%)$ than the measured values for all stations and seasons (except DJF at Barentsburg). After correcting for undercatch in the gauges, the total modeled annual precipitation for Ny-Ålesund is similar to the corrected precipitation. For Svalbard Airport, the modeled precipitation is more than twice the corrected precipitation. However, also the measured precipitation at the neighboring sites Barentsburg and Ny-Ålesund is more than twice the values at Svalbard Airport. The reason for the low precipitation at Svalbard Airport is that the Longyearbyen area is sheltered by mountains in most directions.

- For different atmospheric circulation types, the modeled values largely follow the pattern of the observed precipitation but are generally higher than the precipitation corrected for undercatch. For Hopen and Ny-Ålesund, there is good accordance between the amounts of modeled precipitation and of precipitation corrected for undercatch for the most precipitation-contributing circulation types. For Svalbard Airport, the modeled values are more than twice the corrected precipitation for large-scale onshore winds from the sector west to north. For all stations studied, the bias between modeled precipitation and precipitation corrected for undercatch is low for circulation types where cyclones or cyclonic troughs are situated over or close to Spitsbergen.
- The characteristics of the biases between modeled and observed precipitation may be interpreted in the following way: the modeled dataset does give a good general description of the precipitation processes in the Svalbard region, but does not reproduce the local orographic effects depending on the large-scale wind direction. Consequently, models with better topographic resolution and improved description of orographic effects are needed to reproduce local precipitation details, and particularly the rain shadow effect in the Longyearbyen area.

The answers to the two research questions (RQs, see section 1) are accordingly:

- RQ1: There are differences between historical trends based on measured precipitation and trends based on precipitation corrected for undercatch. The relative trends for corrected precipitation are generally $10 \%$ points lower than for measured precipitation. Measurements corrected for gauge undercatch should thus be used to study true precipitation trends in the Arctic.

- RQ2: Downscaled reanalysis (Sval-Imp) does reproduce the main long-term characteristics of annual precipitation, but the linear trends are weaker than for measured precipitation and for precipitation corrected for undercatch. Generally, Sval-Imp produces higher precipitation values than observations, but the bias is strongly reduced by using precipitation corrected for undercatch. However, although the model resolves the orographic effects on a regional scale, the downscaling is not able to reproduce the local orographic effects depending on the large-scale wind direction.

Acknowledgments. The work has been performed under the Norwegian Centre for Climate Services and supported and funded by the Norwegian Environmental Directorate and the Norwegian Meteorological Institute. A special thanks to Pavel Svyashchennikov, SaintPetersburg State University, Russia for providing precipitation data for Barentsburg for the period 19322018. The authors thank the reviewers for insightful and constructive comments.

\section{APPENDIX}

\section{Precipitation for Different Large-Scale Atmospheric Circulation Types}

Observed and modeled precipitation for different large-scale atmospheric circulation types are shown in Fig. A1. 

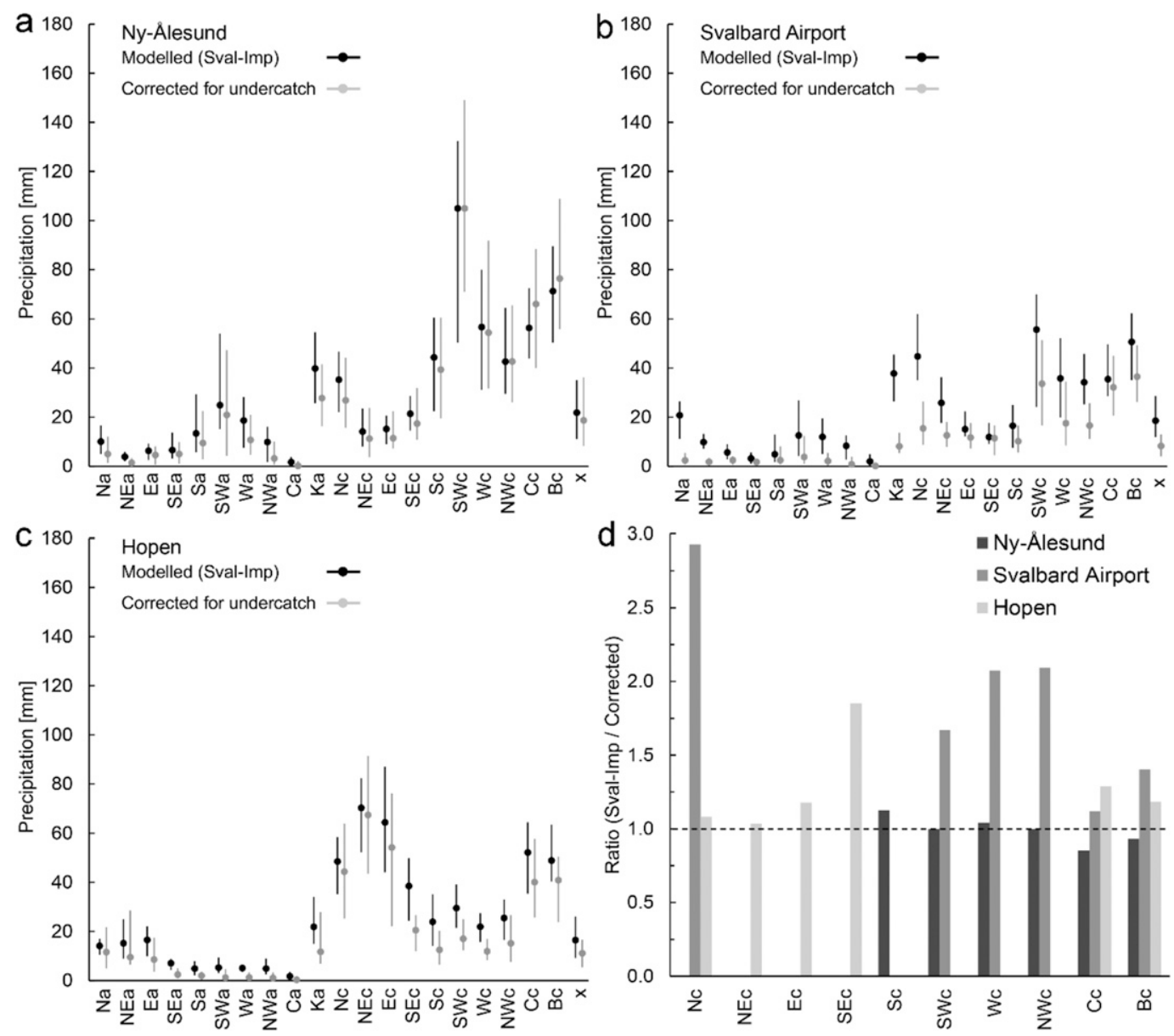

FIG. A1. (a)-(c) Daily precipitation (mm) in Ny-Ålesund, Svalbard Airport, and Hopen, respectively, covering the years 1979-2018, partitioned into different atmospheric circulation types. Black: modeled (Sval-Imp), gray: observed precipitation adjusted for undercatch. Median (dots) and 25th-75th percentiles (whiskers) are shown. (d) The ratio between modeled data and observed precipitation adjusted for undercatch for the six circulation types with the largest contributions to the total precipitation at each station. The circulation types correspond to the geostrophic wind direction assessed using the sea level pressure pattern over Svalbard (Niedźwiedź 2013; Isaksen et al. 2016). The 21 atmospheric circulation types are denoted by capital letters giving the direction of air advection (e.g., $\mathrm{N}=$ northern, $\mathrm{NE}=$ northeastern $)$ and small letters that show the type of pressure system $(\mathrm{a}=$ anticyclone, $\mathrm{c}=$ cyclone $)$. In addition to the 16 types with distinct air advection, the dataset includes four nonadvectional types $(\mathrm{Ca}=$ anticyclonic center over or very close to Spitsbergen, $\mathrm{Ka}=$ anticyclonic ridge, $\mathrm{Cc}=$ center of cyclone over or very close to Spitsbergen, and $\mathrm{Bc}=$ cyclonic trough) and one unclassified type $\mathrm{x}$.

\section{REFERENCES}

Aalstad, K., S. Westermann, T. V. Schuler, J. Boike, and L. Bertino, 2018: Ensemble-based assimilation of fractional snow-covered area satellite retrievals to estimate the snow distribution at Arctic sites. Cryosphere, 12, 247-270, https:// doi.org/10.5194/tc-12-247-2018.

Alexandersson, H., 1986: A homogeneity test applied to precipitation data. J. Climatol., 6, 661-675, https://doi.org/10.1002/ joc.3370060607.

AMAP, 2017: Snow, Water, Ice and Permafrost in the Arctic (SWIPA) 2017. Arctic Monitoring and Assessment Programme, $269 \mathrm{pp}$.

Barstad, I., and R. B. Smith, 2005: Evaluation of an orographic precipitation model. J. Hydrometeor., 6, 85-99, https://doi.org/ 10.1175/JHM-404.1.
Bintanja, T., and O. Andry, 2017: Towards a rain-dominated Arctic. Nat. Climate Change, 7, 263-267, https://doi.org/ 10.1038/nclimate3240.

Botnen, S. S., 2020: Biodiversity in the dark: Root-associated fungi in the Arctic. Ph.D. thesis, University of Oslo, $35 \mathrm{pp}$.

Brown, M. J., and E. L. Peck, 1962: Reliability of precipitation measurements as related to exposure. J. Appl. Meteor., 1, 203-207, https://doi.org/10.1175/1520-0450(1962)001<0203:ROPMAR > 2.0.CO;2.

Crochet, P., T. Jóhannesson, T. Jónsson, O. Sigurð̌sson, H. Björnsson, F. Pálsson, and I. Barstad, 2007: Estimating the spatial distribution of precipitation in Iceland using a linear model of orographic precipitation. J. Hydrometeor., 8, 1285-1306, https:// doi.org/10.1175/2007JHM795.1.

Dee, D. P., and S. Uppala, 2009: Variational bias correction of satellite radiance data in the ERA-Interim reanalysis. Quart. 
J. Roy. Meteor. Soc., 135, 1830-1841, https://doi.org/10.1002/ qj.493.

—, and Coauthors, 2011: The ERA-Interim reanalysis: Configuration and performance of the data assimilation system. Quart. J. Roy. Meteor. Soc., 137, 553-597, https://doi.org/10.1002/qj.828.

Fiddes, J., and S. Gruber, 2014: TopoSCALE v.1.0: Downscaling gridded climate data in complex terrain. Geosci. Model Dev., 7, 387-405, https://doi.org/10.5194/gmd-7-387-2014.

Førland, E. J., and B. Aune, 1985: Comparison of Nordic methods for point precipitation correction. Correction of Precipitation Measurements, B. Sevruk, Ed., Zürcher Geographische Schriften, Vol. 23, ETH Zurich, 239-244.

— Norwegian Arctic: True or false? Climatic Change, 46, 485509, https://doi.org/10.1023/A:1005613304674.

$\longrightarrow, \ldots$, and Ø. Nordli, 1997a: Climate statistics and long-term series of temperature and precipitation at Svalbard and Jan Mayen. MET Norway Rep. 21/97, 72 pp.

,-- , and $-1997 \mathrm{~b}$ : Orographic precipitation at the glacier Austre Brøggerbreen, Svalbard. MET Norway Rep. 02/97, 45 pp.

- - R. E. Benestad, I. Hanssen-Bauer, J. E. Haugen, and T. E. Skaugen, 2011: Temperature and precipitation development at Svalbard 1900-2100. Adv. Meteor., 2011, 1-14, https:// doi.org/10.1155/2011/893790.

Gjelten, H. M., and Coauthors, 2016: Air temperature variations and gradients along the coast and fjords of western Spitsbergen. Polar Res., 35, 29878, https://doi.org/10.3402/polar.v35.29878.

Goodison, B. E., P. Y. T. Louie, and D. Yang, 1998: WMO solid precipitation measurement intercomparison. WMO/TD 872, World Meteorological Organization, 212 pp.

Hanssen-Bauer, I., 2002: Temperature and precipitation in Svalbard 1912-2050: Measurements and scenarios. Polar Rec., 38, 225 232, https://doi.org/10.1017/S0032247400017757.

— , E. J. Førland, and Ø. Nordli, 1996: Measured and true precipitation at Svalbard. MET Norway Rep. 31/96 KLIMA, 49 pp.

,-- H. Hisdal, and S. Mayer, 2017: Climate in Norway 2100 - A knowledge base for climate adaptation. NCCS Rep. 1/2017, 47 pp., https://cms.met.no/site/2/klimaservicesenteret/ rapporter-og-publikasjoner/_attachment/11592?_ts=15c10419731.

$-,-\longrightarrow,-$ A. B. Sand $\varnothing$, and A. Sorteberg, 2019: Climate in Svalbard 2100-A knowledge base for climate adaptation. NCCS Rep. 1/2019, 205 pp., https://cms.met.no/ site/2/klimaservicesenteret/rapporter-og-publikasjoner/_attachment/ $14442 ?$ ts $=168 \mathrm{a} 8 \mathrm{~d} 63 \mathrm{a} 73$.

Hartmann, D. L., and Coauthors, 2013: Observations: Atmosphere and surface. Climate Change 2013: The Physical Science Basis, T. F. Stocker et al., Eds., Cambridge University Press, 159254.

Heberden, W., 1769: On the different quantities of rain which appear to fall at different heights over the same spot of ground. Philos. Trans. Roy. Soc. London, 59, 359-362, https://doi.org/ 10.1098/RSTL.1769.0047.

Isaksen, K., Ø. Nordli, E. J. Førland, E. Łupikasza, S. Eastwood, and T. Niedźwiedź, 2016: Recent warming on Spitsbergen-Influence of atmospheric circulation and sea ice cover. J. Geophys. Res. Atmos., 121, 11 913-11 931, https://doi.org/10.1002/2016JD025606.

Jarosch, A. H., F. S. Anslow, and G. K. C. Clarke, 2012: Highresolution precipitation and temperature downscaling for glacier models. Climate Dyn., 38, 391-409, https://doi.org/ 10.1007/s00382-010-0949-1.

Mestre, O., and Coauthors, 2013: HOMER: A homogenization software - methods and applications. Idojaras, 117, 47-67.
Niedźwiedź, T., 2013: The atmospheric circulation. Climate and Climate Change at Hornsund, Svalbard, A. A. Marsz and A. Styszyńska, Eds., Publishing House of Gdynia Maritime University, 57-74.

Nordli, Ø., A. Przybylak, A. E. J. Ogilvie, and K. Isaksen, 2014: Long-term temperature trends and variability on Spitsbergen: The extended Svalbard Airport temperature series 1898-2012. Polar Res., 33, 21349, https://doi.org/10.3402/polar.v33.21349.

_ I. I. Hanssen-Bauer, and E. J. Førland, 1996: Homogeneity analysis of temperature and precipitation series from Svalbard and Jan Mayen. MET Norway Rep. 16/96, Norwegian Meteorological Institute, $41 \mathrm{pp}$.

Østby, T. I., T. V. Schuler, J. O. Hagen, R. Hock, J. Kohler, and C. H. Reijmer, 2017: Diagnosing the decline in climatic mass balance of glaciers in Svalbard over 1957-2014. Cryosphere, 11, 191-215, https://doi.org/10.5194/tc-11-191-2017.

Overland, J., E. Hanna, I. Hanssen-Bauer, S.-J. Kim, J. Walsh, M. Wang, U. S. Bhatt, and R. L. Thoman, 2018: Surface air temperature [in "State of the Climate in 2017"]. Bull. Amer. Meteor. Soc., 99 (8), S144-S146, https://doi.org/10.1175/ 2018BAMSStateoftheClimate.1.

Peterson, T. C., and Coauthors, 1998: Homogeneity adjustments of in situ atmospheric climate data: A review. Int. J. Climatol., 18, 1493-1517, https://doi.org/10.1002/(SICI)1097-0088(19981115)18: 13<1493::AID-JOC329>3.0.CO;2-T.

Rapaić, M., R. Brown, M. Markovic, and D. Chaumont, 2015: An evaluation of temperature and precipitation surfacebased and reanalysis datasets for the Canadian Arctic, 19502010. Atmos.-Ocean, 53, 283-303, https://doi.org/10.1080/ 07055900.2015 .1045825$.

Schuler, T. V., 2018: Svalbard impact assessment forcing dataset, version 1. Norstore, accessed 15 May 2019, https://doi.org/ $10.11582 / 2018.00006$.

— , and T. I. Østby, 2020: Sval_Imp: A gridded forcing dataset for climate change impact research on Svalbard. Earth Syst. Sci. Data, 12, 875-885, https://doi.org/10.5194/essd-12-875-2020.

_ P. Crochet, R. Hock, M. Jackson, I. Barstad, and T. Johannesson, 2008: Distribution of snow accumulation on the Svartisen ice cap, Norway, assessed by a model of orographic precipitation. Hydrol. Processes, 22, 3998-4008, https://doi.org/10.1002/hyp.7073.

Serreze, M. C., A. P. Barrett, A. G. Slater, M. Steele, J. Zhang, and K. E. Trenberth, 2007: The large-scale energy budget of the Arctic. J. Geophys. Res. 112, D11122, https://doi.org/10.1029/ 2006JD008230.

$\longrightarrow,-$, and J. Stroeve, 2012: Recent changes in tropospheric water vapor over the Arctic as assessed from radiosondes and atmospheric reanalyses. J. Geophys. Res., 117, D10104, https:// doi.org/10.1029/2011JD017421.

Sevruk, B., 1982: Methods of correction for systematic error in point precipitation measurement for operational use. WMO Operational Hydrology Rep. 21, 91 pp.

Smith, R. B., and I. Barstad, 2004: A linear theory of orographic precipitation. J. Atmos. Sci., 61, 1377-1391, https://doi.org/ 10.1175/1520-0469(2004)061<1377:ALTOOP>2.0.CO;2.

Steffensen, E. L., Ø. Nordli and I. Hanssen-Bauer, 1996: Station history for Norwegian meteorological measurements in the Arctic (in Norwegian). MET Norway Rep. Klima 17/96, 44 pp.

Uppala, S. M., and Coauthors, 2005: The ERA-40 Re-Analysis. Quart. J. Roy. Meteor. Soc., 131, 2961-3012, https://doi.org/10.1256/qj.04.176.

Vihma, T., and Coauthors, 2014: Advances in understanding and parameterization of small-scale physical processes in the marine Arctic climate system: A review. Atmos. Chem. Phys., 14, 9403-9450, https://doi.org/10.5194/acp-14-9403-2014. 
and Coauthors, 2016: The atmospheric role in the Arctic water cycle: A review on processes, past and future changes, and their impacts. J. Geophys. Res. Biogeosci., 121, 586-620, https://doi.org/10.1002/2015JG003132.

Vikhamar-Schuler, D., E. J. Førland, J. Lutz, and H. M. Gjelten, 2019: Evaluation of downscaled reanalysis and observations for Svalbard - Background report for Climate in Svalbard 2100. NCCS Rep. 4/2019, 54 pp., https://cms.met.no/site/2/ klimaservicesenteret/rapporter-og-publikasjoner/_attachment/ $14514 ?$ ts $=168 f 0 \mathrm{e} 505 \mathrm{~b} 7$.

Willett, K. M., C. N. Williams Jr., R. J. Dunn, P. W. Thorne, S. Bell, M. D. Podesta, P. D. Jones, and D. E. Parker, 2013: HadISDH: An updateable and surface specific humidity product for climate monitoring. Climate Past, 9, 657-677, https://doi.org/ 10.5194/cp-9-657-2013.

WMO, 2017: Manual on Codes, International Codes, Vol. I.1. WMO-306, 454 pp., https://www.wmo.int/pages/prog/www/ WMOCodes/WMO306_vI1/Publications/2017update/WMO306_ vI1_2011UP2017_en.pdf.
Wolff, M. A., K. Isaksen, R. Brækkan, E. Alfnes, A. PetersenØverleir, and E. Ruud, 2013: Measurements of wind-induced loss of solid precipitation: Description of a Norwegian field study. Hydrol. Res., 44, 35-43, https://doi.org/10.2166/ nh.2012.166.

_ — , A. Petersen-Øverleir, K. Ødemark, T. Reitan, and R. Brækkan, 2015: Derivation of a new continuous adjustment function for correcting wind-induced loss of solid precipitation: Results of a Norwegian field study. Hydrol. Earth Syst. Sci., 19, 951-967, https://doi.org/10.5194/hess19-951-2015.

Yang, D., D. Kane, Z. Zhang, D. Legates, and B. Goodison, 2005: Bias corrections of long-term (1973-2004) daily precipitation data over the northern regions. Geophys. Res. Lett., 32 L19501, https://doi.org/10.1029/2005GL024057.

Zhang, X., J. He, J. Zhang, I. Polaykov, R. Gerdes, J. Inoue, and P. Wu, 2013: Enhanced poleward moisture transport and amplified northern high-latitude wetting trend. Nat. Climate Change, 3, 47-51, https://doi.org/10.1038/nclimate1631. 